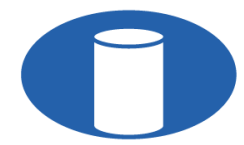

IBRACON Structures and Materials Journal

Revista IBRACON de Estruturas e Materiais

IBRACON

ISSN 1983-4195

ismj.org

ORIGINAL ARTICLE

\title{
Crestbond shear connector for load transfer on concrete filled composite columns in fire
}

\section{Conector Crestbond para transferência de carga em pilares mistos preenchidos com concreto em situação de incêndio \\ Luiz Fernando Pereira do Prado ${ }^{a}$ \\ Larice Gomes Justino Miranda $a^{\mathrm{a}}(1)$ \\ Rodrigo Barreto Caldas ${ }^{\mathrm{a}}$ (D)

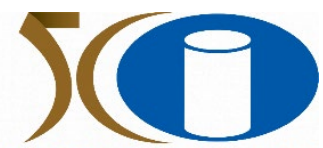 \\ YEARSIBRACON}

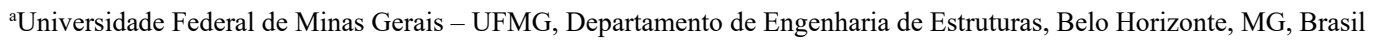

Received 18 September 2020

Accepted 02 Mach 2021

\begin{abstract}
This paper presents a numerical study of the Crestbond shear connector, characterized by a steel plate with regular cuttings, when used as a load transfer element in concrete filled composite columns in fire. The developed numerical model was calibrated with experimental results of composite columns in fire and later the load transfer devices were inserted. Numerical analyzes were performed with the software Abaqus and comprised the variation of the composite column diameter and of the loading levels, as well as the comparison with the results obtained when is used a through steel plate without cuttings (Shear Flat) as a load transfer device. With the analyzes performed, it was observed that the Crestbond shear connector and the Shear Flat present very similar thermomechanical performance in relation to the load transfer capacity. Thus, the Crestbond shear connector has the potential to be applied alternatively to the Shear Flat as a load transfer device in concrete filled composite columns, with the advantage of the possibility of associate use of longitudinal and manly transverse reinforcement.
\end{abstract}

Keywords: concrete filled composite column, load transfer, shear connector, shear flat, fire.

Resumo: Esse trabalho apresenta um estudo numérico do conector Crestbond, caracterizado por uma chapa de aço com recortes regulares trapezoidais, quando utilizado como elemento para transferência de cargas em pilares mistos preenchidos com concreto em situação de incêndio. O modelo numérico desenvolvido foi calibrado com resultados experimentais de pilares mistos em situação de incêndio e posteriormente foram inseridos os elementos de transmissão de carga. As análises numéricas foram realizadas com o auxílio do software Abaqus e compreenderam a variação do diâmetro do pilar misto e dos níveis de carregamento, bem como a comparação com os resultados obtidos quando é utilizada uma chapa de aço passante sem recortes como dispositivo de transferência de carga. Com as análises realizadas, observou-se que o conector Crestbond e a chapa passante apresentam desempenho termomecânico muito semelhantes em relação à capacidade de transferência de carga. Sendo assim, o conector Crestbond tem potencial para ser aplicado em alternativa à chapa passante como dispositivo de transferência de carga em pilares mistos preenchidos, tendo como vantagem a possibilidade do uso associado de barras de armadura longitudinais e, principalmente, transversais.

Palavras-chave: pilar misto preenchido com concreto, transferência de carga, conector de cisalhamento, chapa passante, incêndio.

How to cite: L. F. P. Prado, L. G. J. Miranda and R. B. Caldas, "Crestbond shear connector for load transfer on concrete filled composite columns in fire," Rev. IBRACON Estrut. Mater., vol. 15, no. 3, e15310, 2022, https://doi.org/10.1590/S1983-41952022000300010 


\section{INTRODUCTION}

The concrete filled composite column (CFCC) are basically composed of an external steel tube and a concrete core, the interaction of which provides greater resistance and ductility when compared to the individual application of each of these components [1]. To ensure the interaction between the components of the composite columns and thus an adequate load transfer, shear connectors can be used, especially in the region where loads are introduced [1], [2]. In view of this premise and the need for the load transfer devices used to be compatible with the use of reinforcement and easy to install, a constructive solution was developed at the Federal University of Minas Gerais, which consists of using Crestbond shear connectors as load transfer device at the steel-concrete interface, while integrating the beam-column connection [3]-[8] (Figure 1).

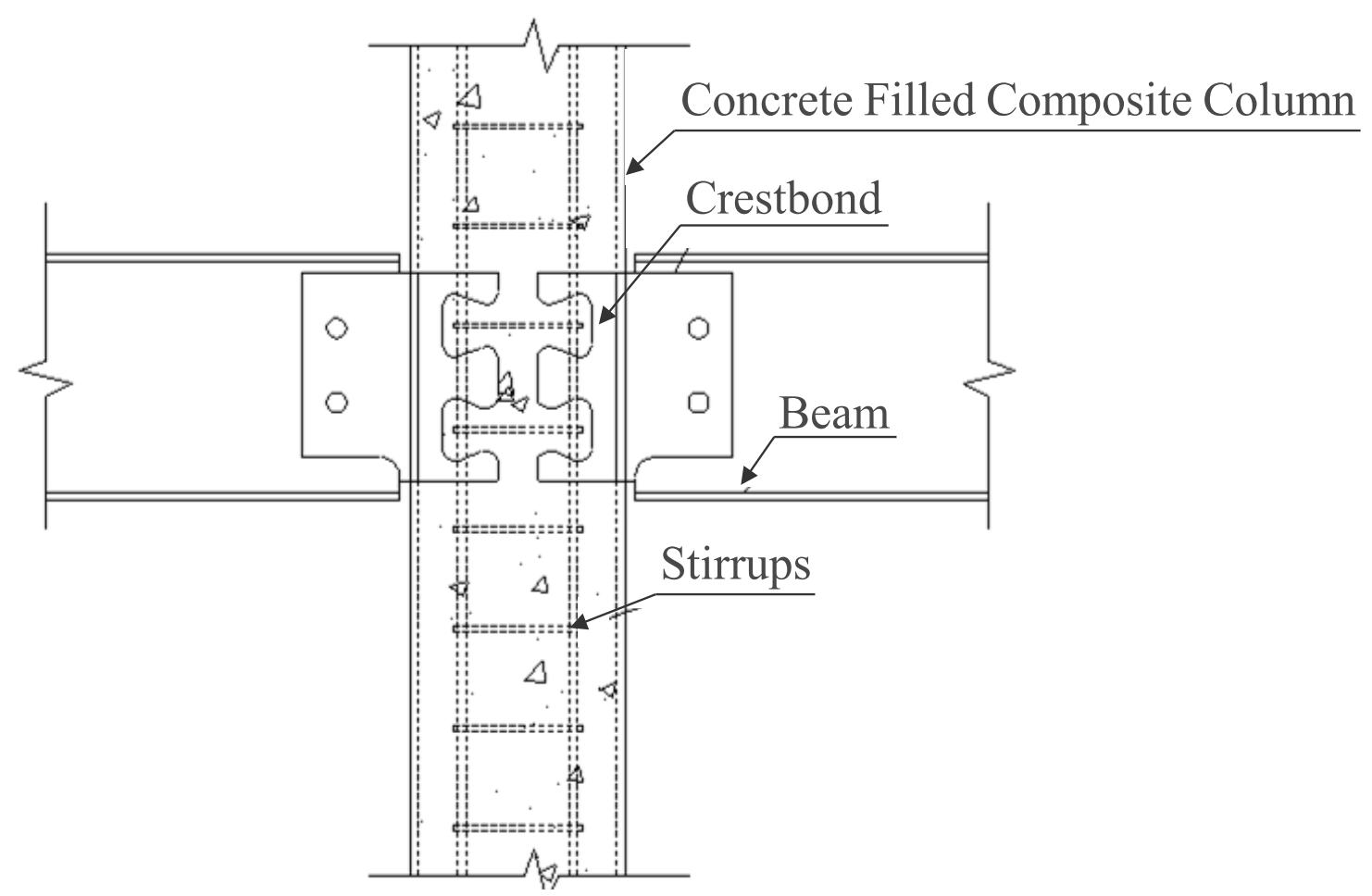

Figure 1. Crestbond shear connector as load transfer device [3].

Given the possibility of the widespread use of this constructive solution and the growing concern with the safety and integrity of the structures, it is essential to study it also in fire, since, as the temperature rises, the resistance and stiffness of steel and concrete degrade, which can lead to structural failure or states of excessive deformation. For the specific case of the load transfer device studied, it is also noteworthy that the thermal expansion can cause excessive cracking of concrete, especially in the connection region, resulting in a reduction in the resistance of the CFCC.

Thus, in this work, a numerical study was carried out, using Abaqus software, on the thermomechanical behavior of the Crestbond shear connector used as a load transfer device in CFCC of circular cross section, considering the dimensional variation of the steel tube, different load levels, the effect of thermal expansion and the comparison with the use of plates without cuttings (Shear Flats).

\section{LITERATURE REVIEW}

The Crestbond shear connector (Figure 2) consists of a steel plate with regular cuttings, which favor the arrangement of the reinforcements and promote the confinement of concrete [9]. Although this type of composite dowel connection was conceived for application in composite beams [10]-[13], its application as a device for transferring loads in composite columns (Figure 1) has shown to be promising. 


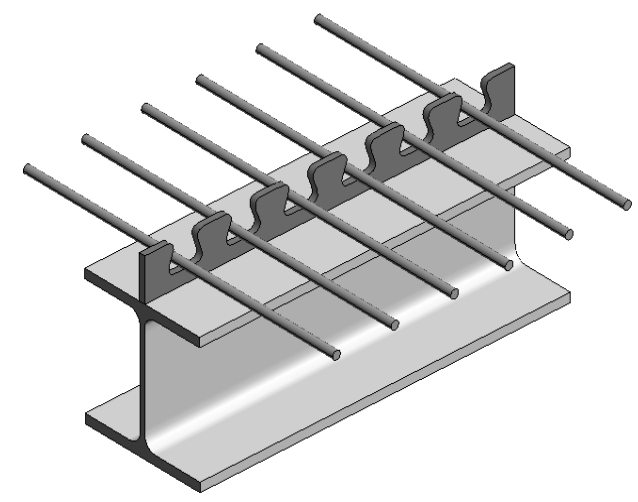

Figure 2. Composite beam with Crestbond shear connector [9].

Oliveira et al. [3] and Cardoso [7] carried out an experimental study composed of CFCCs of circular and rectangular cross section in which the Crestbond shear connector was applied as a load transfer device. The tests were conducted based on the guidelines in annex B of EN 1994-1-1:2004 [14] for standard push test (Figure 3a), and the results obtained were used for the development of a representative numerical model [4]-[6] (Figure 3b). This finite element (FE) model was created in Abaqus using 8-node brick elements (C3D8), with seed size of $8 \mathrm{~mm}$ in the Crestbond and surroundings. A classic elastoplastic model was used to simulate the steel and the Concrete Damaged Plasticity model was used to simulate the concrete. The load was gradually increased by Riks method.

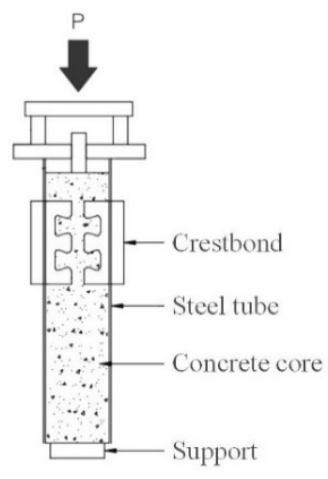

a)

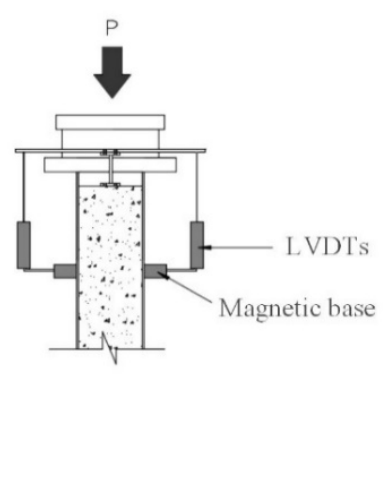

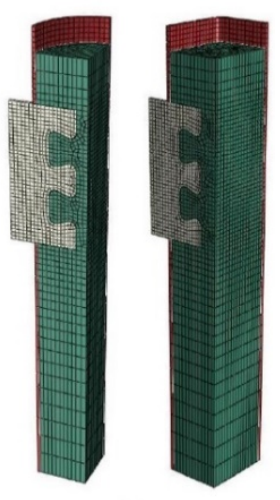

b)

Figure 3. a) Test setup [7] and b) numerical model [4] in ambient temperature.

Although this structural solution is promising, there is no research on its structural behavior in fire, being an alternative, for the constitution of numerical models, to add the load transfer devices in the validated numerical models of CFCC in fire.

The numerical models of CFCC in fire developed by Hong and Varma [15] and Wang and Young [16] in Abaqus software basically comprise an uncoupled thermomechanical analysis, in which, in the first step (thermal analysis), the model is discretized with 8-node linear brick elements (DC3D8) and, in the later step (mechanical analysis), which starts from the results achieved in the first step, C3D8 elements are used. Espinós et al. [17] and Pires et al. [18] used the same methodology above, however, Espinós et al. [17] used elements with reduced integration in the mechanical analysis step and Pires et al. [18] used the elements C3D20R and DC3D20 of 20 nodes, in the first and second steps, respectively. Laím et al. [19] performed a coupled thermomechanical analysis, so that initially axial loading is applied and then the temperature rise is considered. The model was discretized with 8-node displacement and temperature solid elements with reduced integration (C3D8RT).

In these works, it is observed the need for adjustments in the models present in the technical standards that represent the characteristics of the materials with the increase in temperature, especially of concrete, which is confined by the steel tube, and the definition of an initial imperfection level aiming the calibration of the FE model. 


\section{NUMERICAL MODELING}

Given the absence of experimental CFCC models with Crestbond shear connectors as a load transfer device in fire, a numerical CFCC model was initially developed, which was validated with experimental results and, subsequently, the shear connectors were added to the validated model.

\subsection{CFCC at elevated temperatures}

The CFCC FE model in fire was developed in Abaqus software, based on the methodology employed by Espinós et al. [17] and considering the symmetry of the models. The analysis was performed in an uncoupled manner and in two sequential steps, the first being a thermal analysis and the second a mechanical analysis with prescribed temperatures, according to the previous analysis.

In the thermal analysis step, the properties of steel and concrete were defined according to EN 1992-1-2:2004 [20], EN 1993-1-2:2005 [21] and EN 1994-1-2:2005 [22], the model was subjected to standard fire [23]-[24] and, at the materials interface, a thermal conductivity coefficient equal to $200 \mathrm{~W} / \mathrm{m}^{2} \mathrm{~K}$ [17] was adopted. The models were discretized with DC3D8 elements, with seed size of $10 \mathrm{~mm}$, defined through a mesh refinement study.

In the mechanical analysis step, the data from the previous analysis were imported and, for the concrete, in addition to the properties provided in the European Standard, those provided in Lie [25] were considered. In this step, the FE models were discretized with C3D8R elements, and a thermal expansion coefficient equal to $6.10^{-6}{ }^{\circ} \mathrm{C}^{-1}$ was considered for concrete, according to Hong and Varma [15].

An isotropic elastoplastic model with the Von Mises yield criterion was used to representing the mechanical behavior of steel and the Concrete Damaged Plasticity (CDP) model was selected for characterizing the mechanical behavior of concrete. The input parameters used in CDP model are presented in Table 1.

Table 1. Parameters adopted in CDP model.

\begin{tabular}{ccc}
\hline Parameter & Value & $36^{\circ}$ \\
\hline Dilation angle $(\psi)$ & 1.16 & 0.8 \\
\hline Biaxial/uniaxial compressive strength ratio $\left(\sigma_{b 0} / \sigma_{c 0}\right)$ & 0.1 \\
\hline Parameter for defining the yield surface $(K)$ & Viscosity parameter $(\mu)$ & \\
\hline
\end{tabular}

\subsubsection{Validation of thermal analysis}

The validation of the FE model in the thermal analysis step consisted of comparing the evolution of temperature over time of exposure to fire observed in the numerical simulation and observed in the test. In the Figure 4, the temperatures obtained from the FE model were compared with those measured at the external surface and at various depths of the column 3 from Wang and Young [16]. It was observed that there is a good agreement between the FE and the test results, with the exception of the initial stages of fire exposure, for deeper locations in the concrete core. This difference might be due the water evaporation and the mass transfer that were simulated approximately by modifying the specific heat.

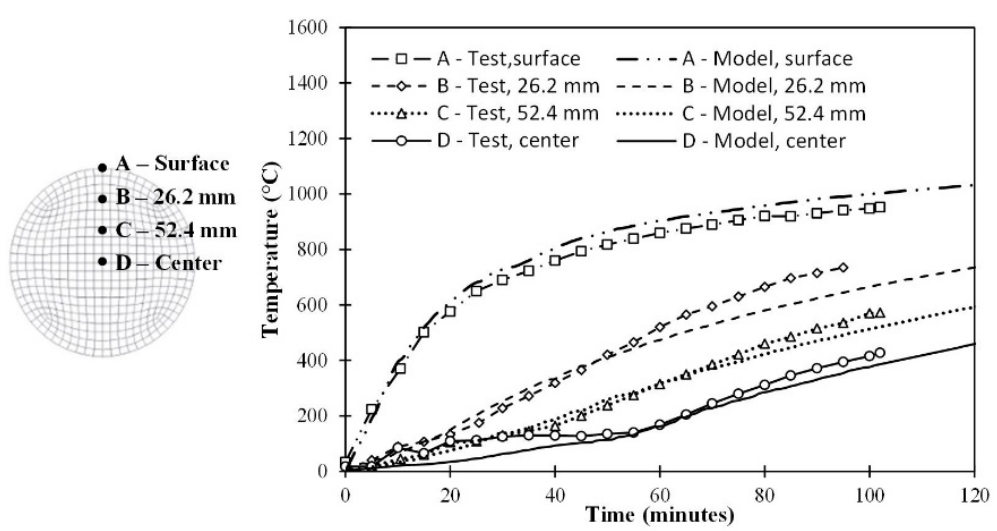

Figure 4. Time-temperature relationships obtained experimentally by Wang and Young [16] and numerically in this paper for column 3. 


\subsubsection{Validation of decoupled thermal and mechanical analyzes}

To validate the decoupled thermal and mechanical analyses, the models C-05, C-13 and C-17 from Espinós et al. [17] were simulated. These models consist of three parts: the concrete core, the steel tube and the loading plate (Figure 5). The CFCC top, which was in contact with the rigid loading plate, had free translation and the CFCC bottom had fixed translation. An initial imperfection of $0.1 \%$ of the CFCC depth and a friction coefficient equal to 0.55 in the steel-concrete interface were considered. The comparison between the axial displacements measured in the test and predicted by the FE model (Figure 6a), as well as the final deformed configuration (Figure 6b) showed that it is possible to prescribe a model with reasonable precision in relation to the experimental data, despite the high complexity of the numerical simulations and the definition of thermal and mechanical properties of the materials, mainly of the concrete in fire. It should also be noted that the constitutive model of concrete provided by EN 1992-1-2:2004 [20] proved to be more conservative than the Lie's model [25]. Although only the results of model C-17 were presented, similar results and conclusions were observed for models C-05 and C-13.

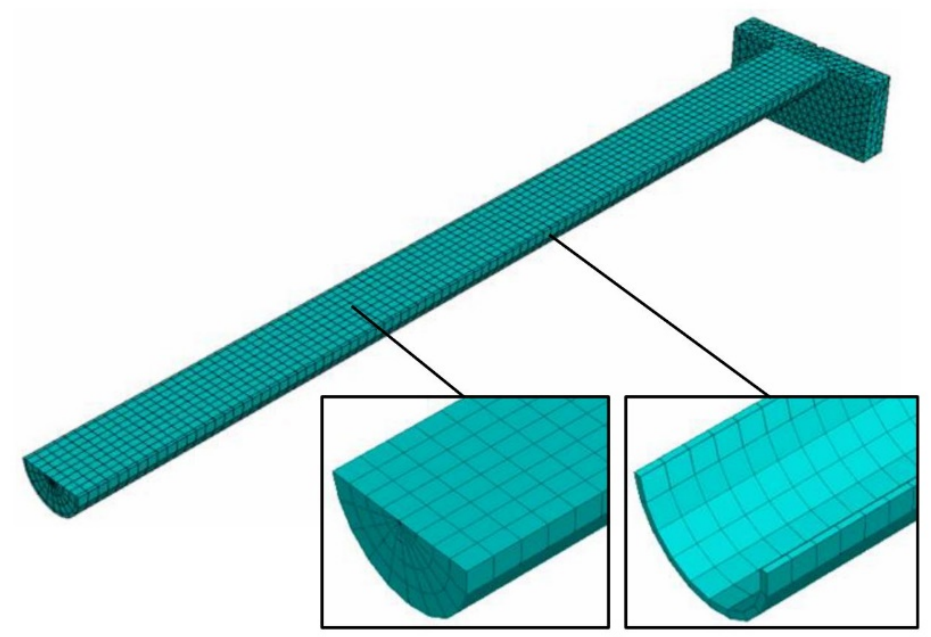

Figure 5. FE model of CFCC with loading plate, concrete core and steel tube in detail (Adapted from [17]).

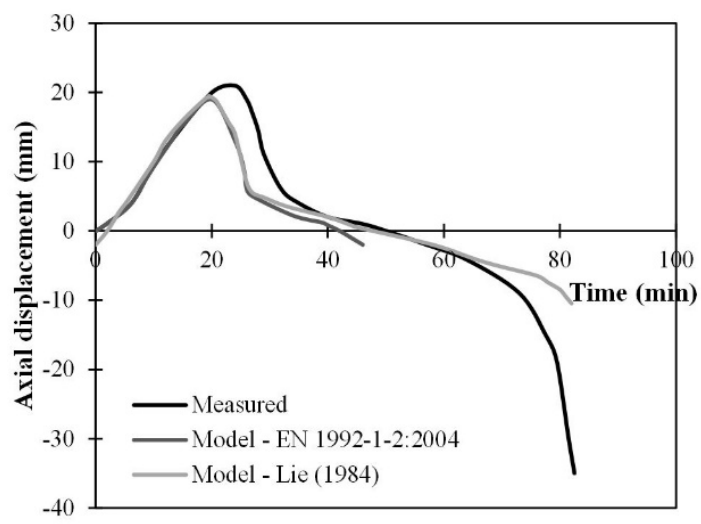

a)

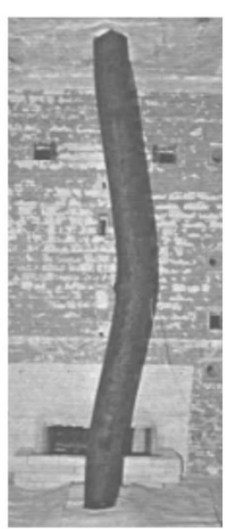

b)

Figure 6. Comparison of measured and predicted a) axial displacement and b) deformed configuration for column C-17.

\subsection{CFCC with load transfer devices at elevated temperatures}

The load transfer devices were added to the validated FE models of CFCC in fire and the analysis occurred in the same way as the previous ones, except for the loading, which was applied directly in the shear connectors. They were modeled $3 \mathrm{~m}$ CFCCs (Figure 7), considering the symmetry of the models, with external diameters $(D)$ of 200, 400 and 
$600 \mathrm{~mm}$, steel tube with a thickness of $8 \mathrm{~mm}$ and load transfer devices (Crestbond and Shear Flat) with height of 292.2 $\mathrm{mm}$ and thickness of $12.5 \mathrm{~mm}$, positioned $150 \mathrm{~mm}$ from the top of the column (Figure 7a). Using multi-point constraint the load was applied in a reference point (RP) located on the outer face of the connector (Figure 7b) with fixed rotations to simulate a beam-column connection. The CFCC top and botton had the longitudinal translation fixed to simulate its continuity like in an intermediate storey. Figures $7 \mathrm{c}$ and $7 \mathrm{~d}$ show the discretization of the mesh with elements of maximum dimensions equal to $8 \mathrm{~mm}$ in the connectors and adjacent concrete with a gradual increase in the longitudinal direction with a length of up to $25 \mathrm{~mm}$ at the top end and up to $50 \mathrm{~mm}$ at the bottom end.

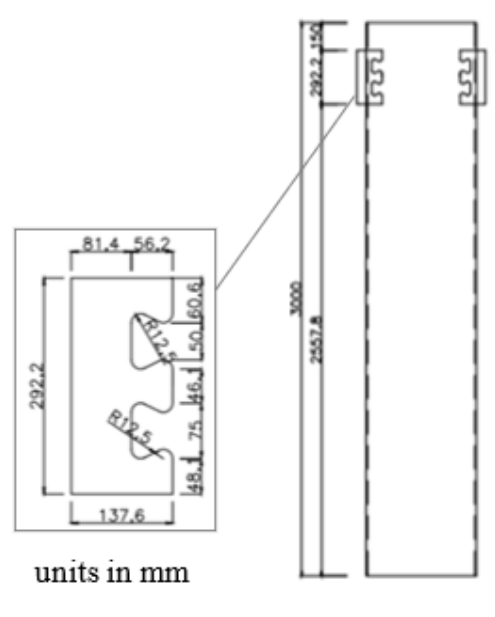

a)

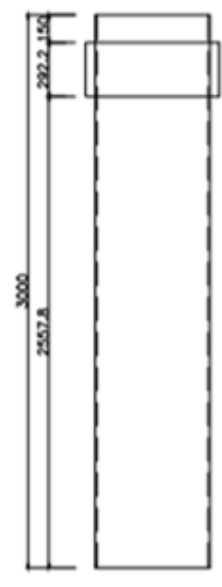

b)

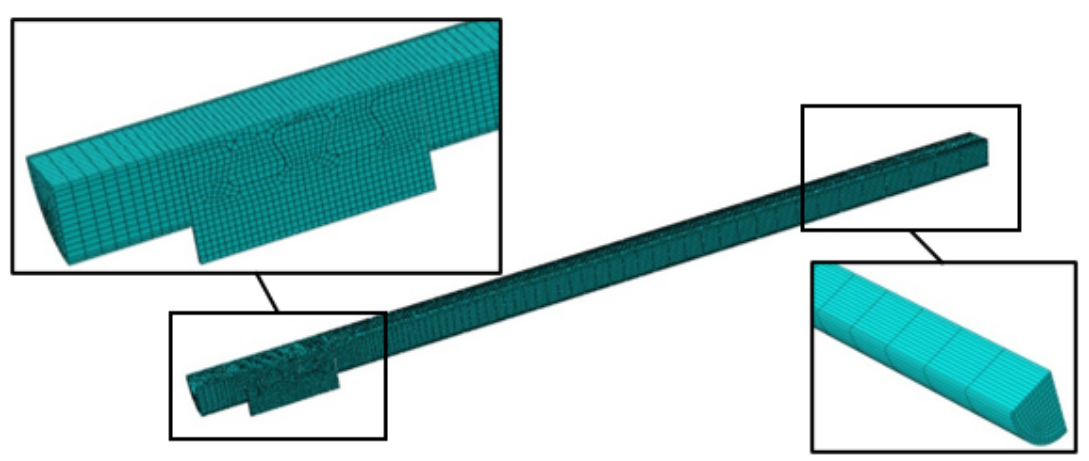

c)

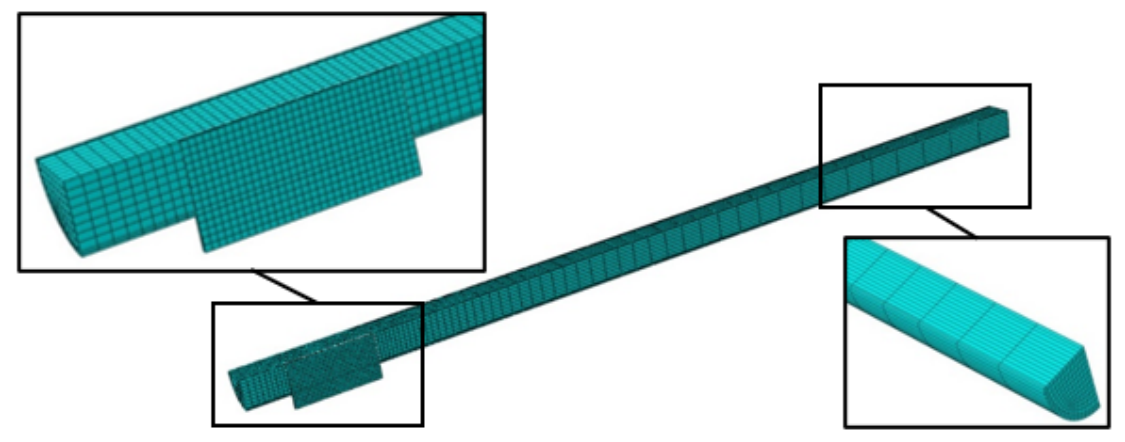

d)

Figure 7. Details of a) CFCC with Crestbond and Shear Flat, b) loading point, c) Crestbond FE model and d) Shear Flat FE model. 
Loads corresponding to fractions of the design resistance at ambient temperature $(676.4 \mathrm{kN})$ were applied and the constitutive model of Lie [25] was used for the characterization of concrete, since this model favored the convergence of the analysis and the obtaining of the resistance at ambient temperature. A yield strength $\left(f_{y}\right)$ of $345 \mathrm{MPa}$ was adopted for the steel of the tube and of the shear connector and a compressive strength $\left(f_{c}\right)$ of $40 \mathrm{MPa}$ was adopted for the concrete.

Figure 8 presents the results obtained in the numerical simulations for the different diameters and loading levels studied, for the Crestbond shear connector and for the Shear Flat. For the failure time was considered the processing time in the FE models until convergence. Then, the models were analyzed to verify the failure mode, considering the displacement of the connector external edge, strain and stress in steel and concrete. It is possible to observe that, for the diameter of $200 \mathrm{~mm}$, there is no difference between the results obtained for Crestbond and for Shear Flat for load levels above $50 \%$ and that the Crestbond is slightly more resistant than Shear Flat for load levels below 50\%. It can also be noted that, for the diameters of 400 and $600 \mathrm{~mm}$, the Shear Flat is more resistant than Crestbond for all load levels. These results are due to the greater mass of the Shear Flat, which results in a slower increase in temperature in this device compared to the Crestbond and, consequently, the lowest reduction in the yield strength of the connector steel $\left(f_{y, \text { connector }}\right)$; and due to the distribution of stresses in a larger area in the concrete core for the Crestbond in $200 \mathrm{~mm}$ diameter CFCC and for the Shear Flat in the other cases.

The contact length of the Crestbond with the concrete core is around $383 \mathrm{~mm}$ regardless of the CFCC diameter, and the contact length of the Shear Flat with the concrete core is $184 \mathrm{~mm}$ for the $200 \mathrm{~mm}$ diameter CFCC, $384 \mathrm{~mm}$ for the $400 \mathrm{~mm}$ diameter CFCC e $584 \mathrm{~mm}$ for the $600 \mathrm{~mm}$ diameter CFCC, i.e., the greater the CFCC diameter the greater the contact length of the Shear Flat. And, the greater the contact length, the greater the area where the stress is distributed and the greater the resistance of the connection, which occurs for Crestbond for the $200 \mathrm{~mm}$ diameter CFCC and in the Shear Flat in the other cases.

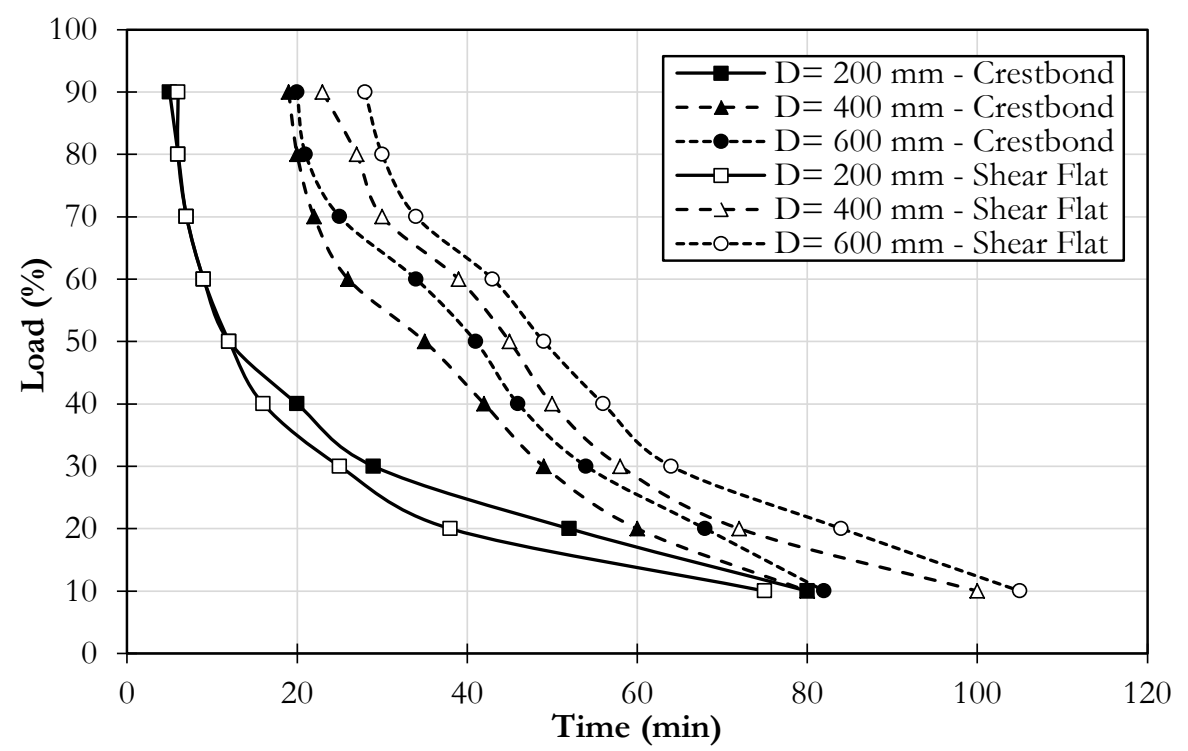

Figure 8. Time-load relationships obtained numerically for CFCC with load transfer devices.

Figures 9 to 12 show the temperature distribution, von Mises stresses, concrete tensile stresses and the deformed configuration of $400 \mathrm{~mm}$ diameter CFCCs with Crestbond shear connector and with Shear Flat for the loading levels of 30 and $50 \%$, as well as the displacement of the central point of the external surface of the connector over time of fire exposure. It was observed that, with the increase in temperature, the consequent reduction in strength and stiffness of the steel tube and the thermal expansion of the CFCC components there was a separation between the concrete core and the steel tube during the fire exposure (Figures $9 \mathrm{c}, 10 \mathrm{~d}, 11 \mathrm{c}$ and $12 \mathrm{c}$ ) and the reduction of the concrete confinement, wherein the Crestbond and the Shear Flat were responsible for maintaining the steel tube and the concrete connected.

It was observed the shear failure of the external part of the load transfer devices (Figure 10d) in the cases where the reduction factor for yield strength $\left(k_{y}\right)$, due to the increase in temperature, reaches a value equal to or less than the load 
level; this failure mode is the same one that occurs at ambient temperature. For the other cases, it was observed a concrete related failure (Figures $9 \mathrm{c}, 11 \mathrm{c}$ and $12 \mathrm{c}$ ), which is due the loss of the concrete confinement, the tensile stresses resulting from the thermal effects and the deformations resulting from the load transfer from the connector to the concrete core. It is noteworthy that the shear failure of the external part of the connector is more common at low load levels $(\leq 30 \%)$, in which higher temperatures are observed at the interface between the connector and the steel tube and hence greater reduction in the yield strength of the connector steel $\left(f_{y, \text { connector }}\right)$.

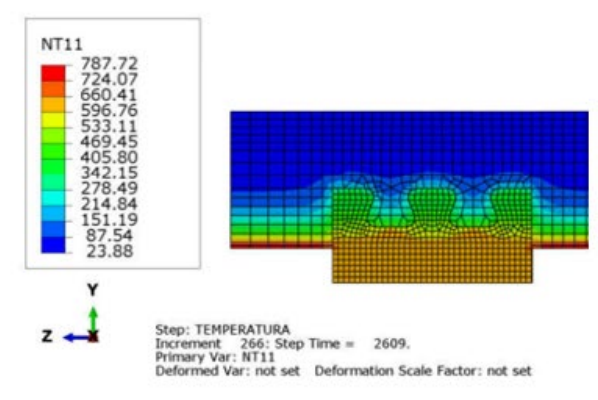

a)

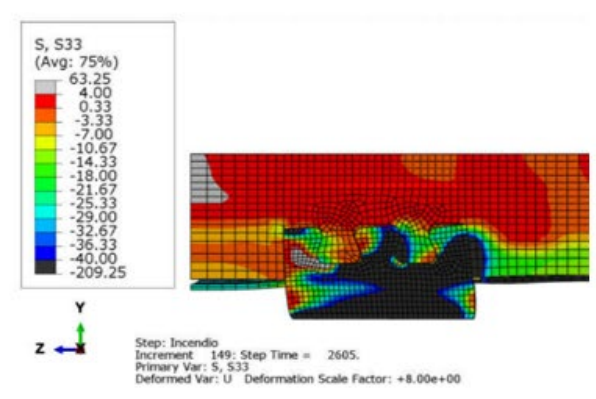

c)

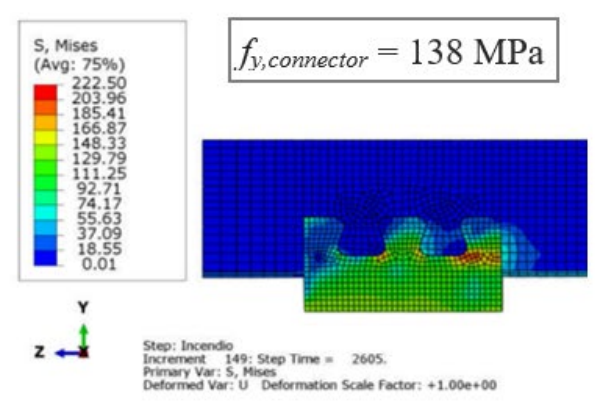

b)

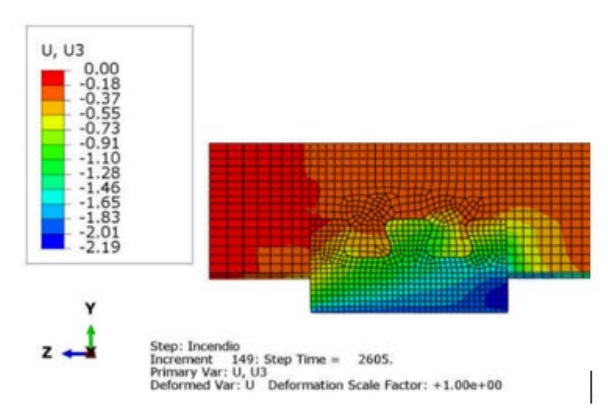

d)

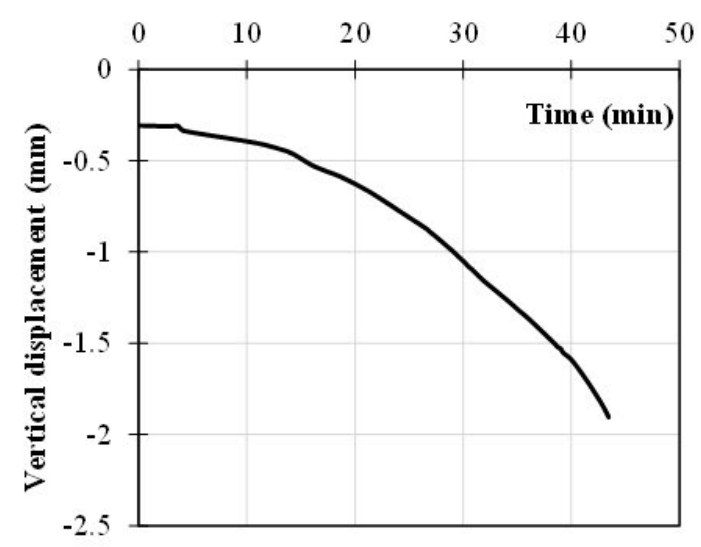

e)

Figure 9. a) Temperature distribution, b) von Mises stresses, c) concrete tensile stresses, d) deformed configuration and e) displacement of the central point of the external surface of the connector of $400 \mathrm{~mm}$ diameter CFCCs with Crestbond shear connector for the loading level of $30 \%$. 


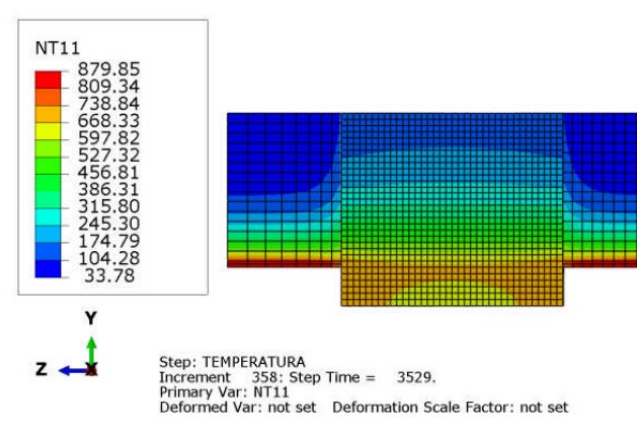

a)

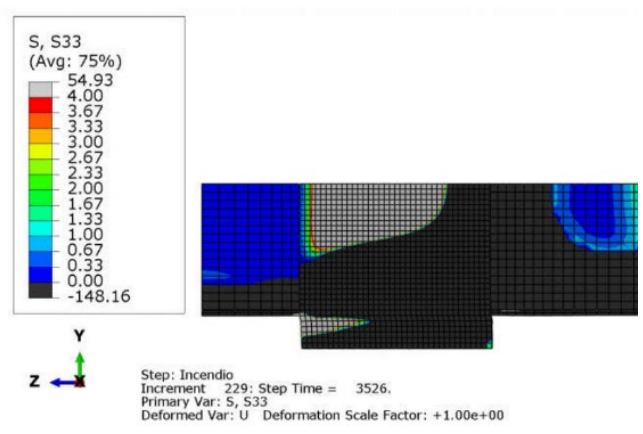

c)

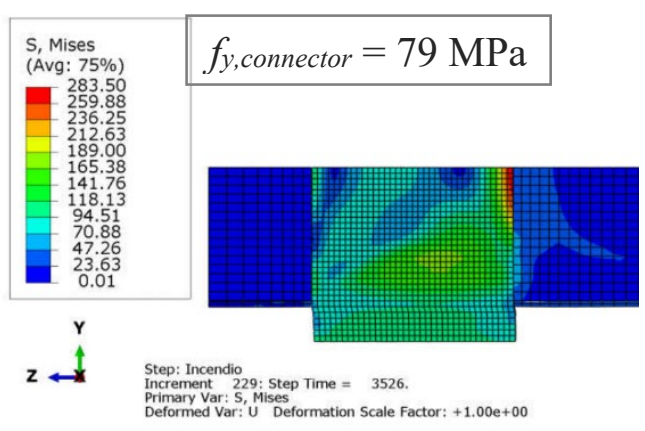

b)

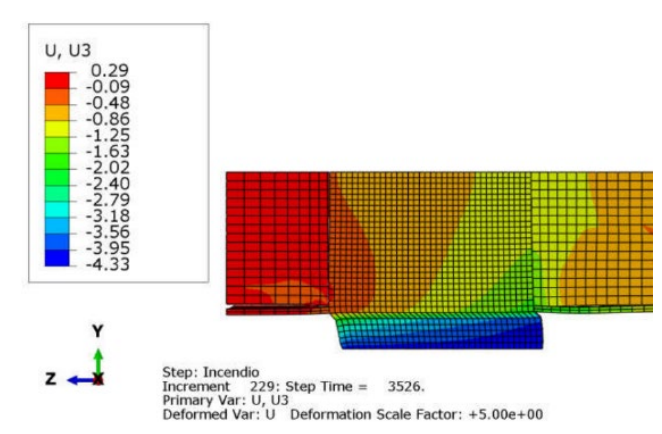

d)

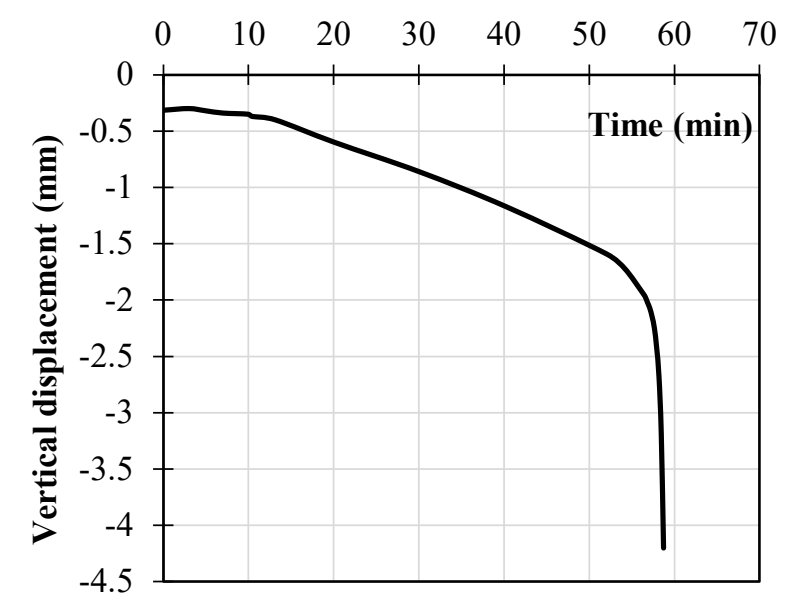

e)

Figure 10. a) Temperature distribution, b) von Mises stresses, c) concrete tensile stresses, d) deformed configuration and e) displacement of the central point of the external surface of the connector of $400 \mathrm{~mm}$ diameter CFCCs with Shear Flat for the loading level of $30 \%$. 


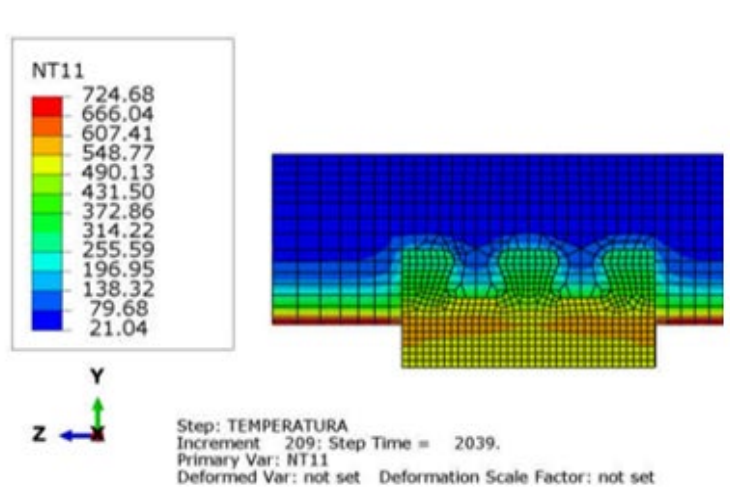

a)

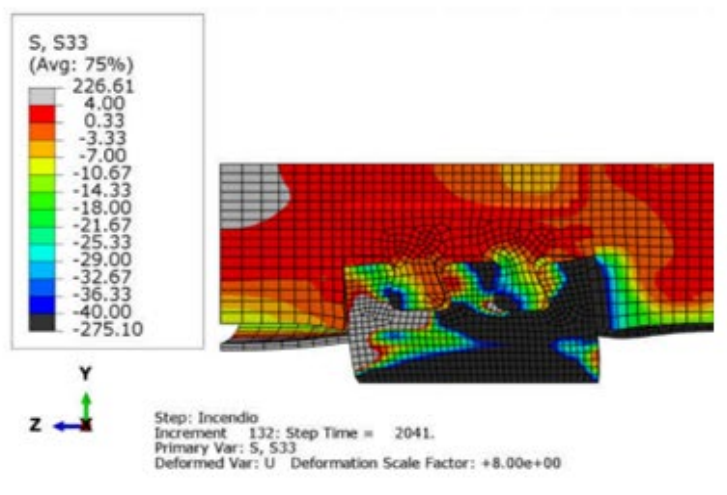

c)

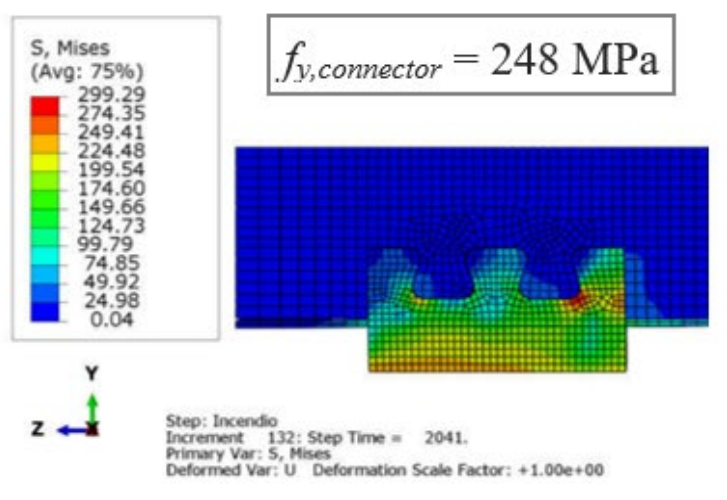

b)

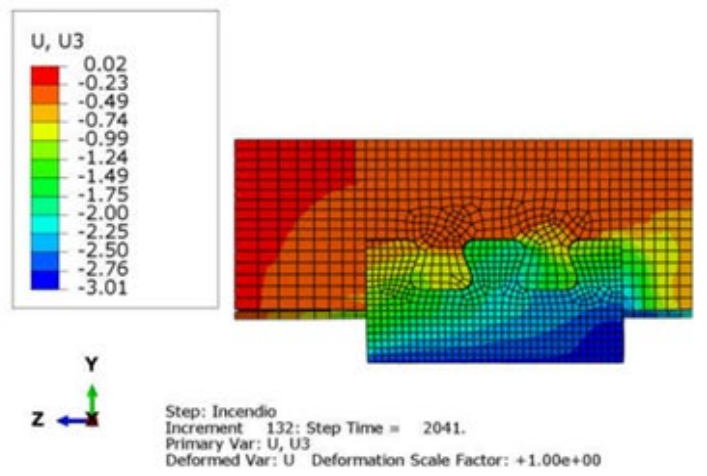

d)

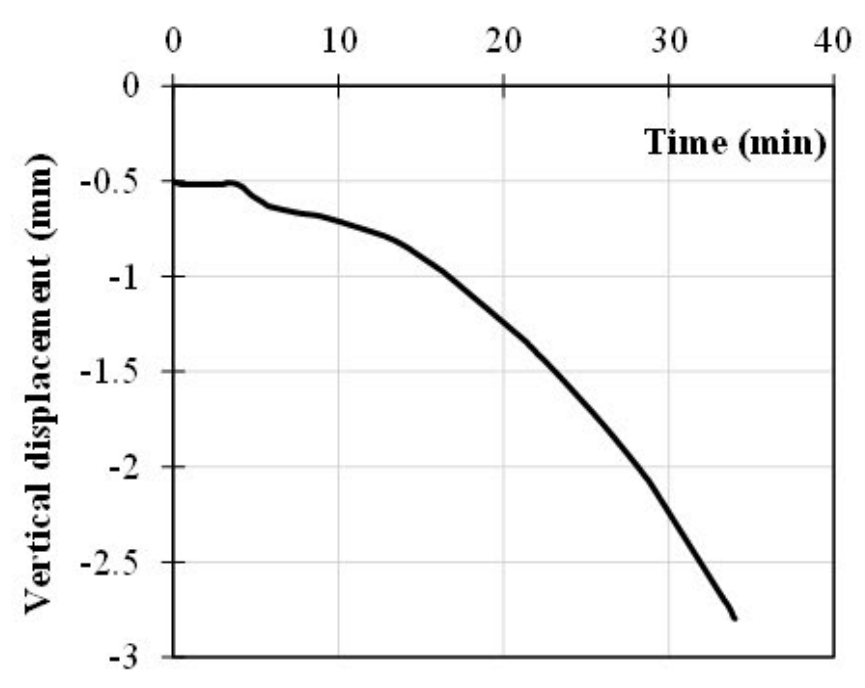

e)

Figure 11. a) Temperature distribution, b) von Mises stresses, c) concrete tensile stresses, d) deformed configuration and e) displacement of the central point of the external surface of the connector of $400 \mathrm{~mm}$ diameter CFCCs with Crestbond shear connector for the loading level of $50 \%$. 


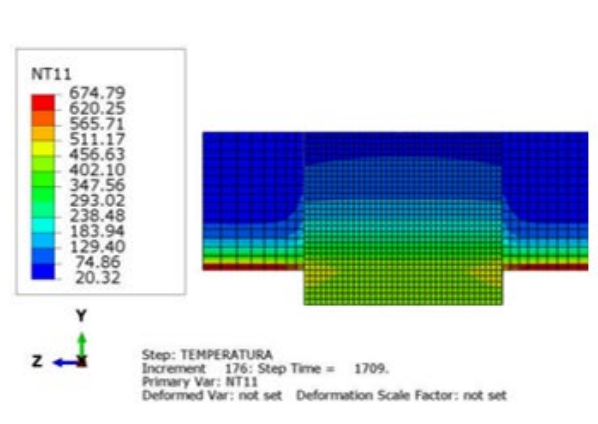

a)

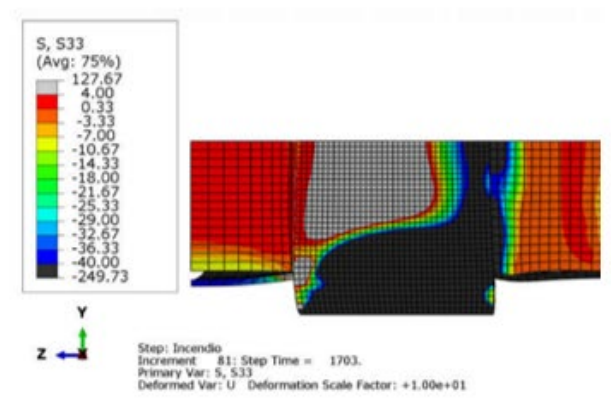

c)

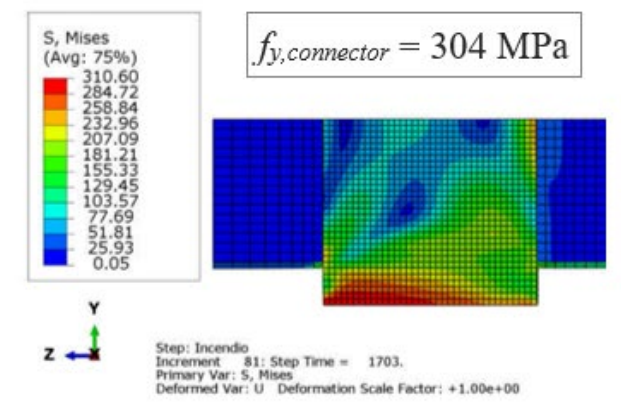

b)

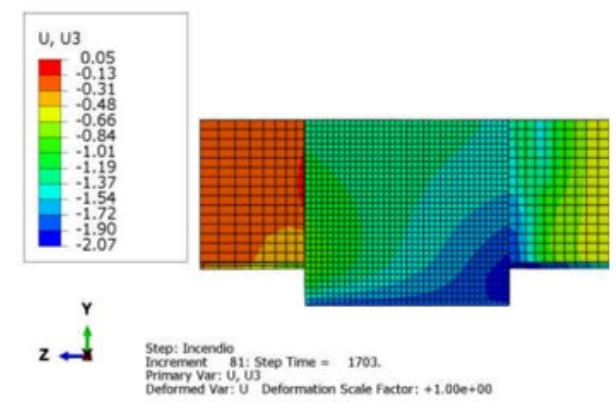

d)

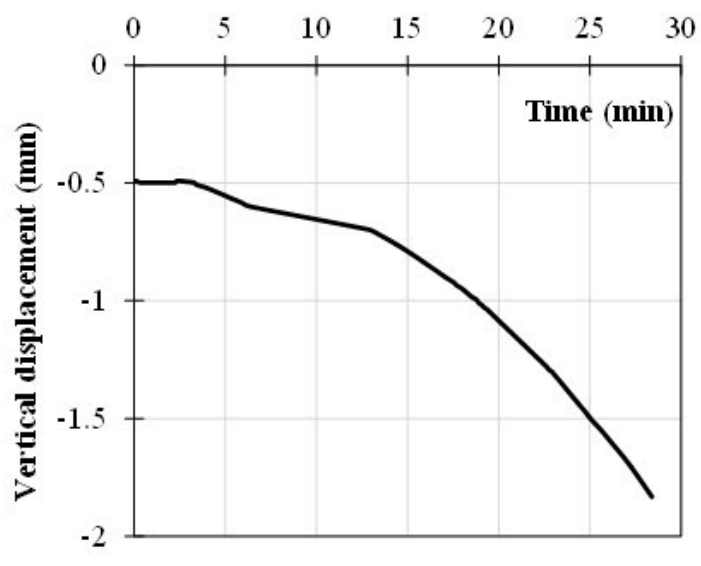

e)

Figure 12. a) Temperature distribution, b) von Mises stresses, c) concrete tensile stresses, d) deformed configuration and e) displacement of the central point of the external surface of the connector of $400 \mathrm{~mm}$ diameter CFCCs with Shear Flat for the loading level of $50 \%$.

\section{CONCLUSIONS}

This paper presents the numerical modeling of CFCCs with load transfer devices (Crestbond and Shear Flat) in fire. With the numerical simulations it was possible to evaluate the resistance and the structural behavior of the studied solutions in face of the temperature rise.

From the curves that relate the failure time and the load level, it was observed that, for smaller diameters, the behavior of Crestbond and Shear Flat is very similar and that, for larger diameters, the Shear Flat proved to be slightly more resistant, given its greater mass and greater contact area with the concrete core. It was also observed that, for low load levels $(\leq 30 \%)$, the failure mode is mostly related to the connector, given the reduction of its resistance with the 
increase in temperature, and that, for load levels above $30 \%$, the failure mode is related to the loss of confinement of the concrete.

No studies were found in which the cost of the two studied solutions (Shear Flat and Crestbond) is compared. However, for larger diameters and, considering a symmetric cut to obtain Crestbond connectors, the cost can be lower than for Shear Flat. For several connections in different radial directions, the Crestbond is a simpler application than the Shear Flat and favors the use of transverse reinforcement. Although Shear Flat has a slightly higher resistance than Crestbond and only with the thermomechanical analyzes performed, it is not possible to conclude which is the best solution in fire and additionally experimental analyzes should be performed. However, the similar performance observed for the load transfer devices analyzed leads to the conclusion that the composite dowel shear connector Crestbond is a potential alternative to the Shear Flat, already standardized by Eurocode.

\section{ACKNOWLEDGEMENTS}

The authors thank FAPEMIG (Fundação de Amparo à Pesquisa do Estado de Minas Gerais), CAPES (Coordenação de Aperfeiçoamento de Pessoal de Nível Superior), CNPq (Conselho Nacional de Desenvolvimento Científico e Tecnológico) and UFMG (Universidade Federal de Minas Gerais) for their financial support in this research.

\section{REFERENCES}

[1] L. H. Han, W. Li, and R. Bjorhovde, "Developments and advanced applications of concrete-filled steel tubular (CFST) structures: Members," J. Construct. Steel Res., vol. 100, pp. 211-228, Sep 2014, http://dx.doi.org/10.1016/j.jcsr.2014.04.016.

[2] W. L. A. Oliveira, “Análise teórico-experimental de pilares mistos preenchidos de seção circular,” Ph.D. dissertation, Escola Eng. de São Carlos, Univ. de São Paulo, São Carlos, SP, Brasil, 2008.

[3] H. M. S. Oliveira et al. "Uso do conector Crestbond em pilares mistos formados por perfis tubulares de aço preenchidos com concreto," in XXXVI Jornadas Sudamericanas de Ingenieria Estructural, Montevidéu, 2014.

[4] O. P. Aguiar, "Estudo do comportamento de conectores Crestbond em pilares mistos tubulares preenchidos com concreto," M.S. thesis, Dept. Eng. Estrut., Univ. Federal de Minas Gerais, Belo Horizonte, MG, Brasil, 2015.

[5] O. P. Aguiar, R. B. Caldas, H. M. S. Oliveira, and R. H. Fakury, "Estudo de conectores Crestbond em pilares mistos preenchidos com concreto," Rev. Estrutura Aco, vol. 4, no. 3, pp. 181-199, Dec 2015.

[6] O. P. Aguiar, R. B. Caldas, F. C. Rodrigues, R. H. Fakury, and G. S. Veríssimo, "Crestbond Shear connectors for load transfer in concrete filled tube columns," Rev. IBRACON Estrut. Mater., vol. 11, no. 5, pp. 960-965, Sep/Oct 2018, http://dx.doi.org/10.1590/s1983-41952018000500004.

[7] H. S. Cardoso "Avaliação do comportamento de conectores constituídos por chapas de aço com recortes regulares - ênfase em conectores de geometria Crestbond aplicados em pilares mistos," Ph.D. dissertation, Dept. Eng. Estrut., Univ. Federal de Minas Gerais, Belo Horizonte, MG, Brasil, 2018.

[8] H. S. Cardoso, O. P. Aguiar, R. B. Caldas, and R. H. Fakury, "Composite dowels as load introduction devices in concrete-filled steel tubular columns," Eng. Struct., vol. 219, pp. 1-15, Sep 2020., http://dx.doi.org/10.1016/j.engstruct.2020.110805.

[9] G. S. Veríssimo, "Desenvolvimento de um conector de cisalhamento em chapa dentada para estruturas mistas de aço e concreto e estudo do seu comportamento," Ph.D. dissertation, Dept. Eng. Estrut., Univ. Federal de Minas Gerais, Belo Horizonte, MG, Brasil, 2007.

[10] C. M. Dutra, "Estudo do comportamento estrutural do conector Crestbond considerando variações geométricas e mecânicas,” M.S. thesis, Dept. Eng. Civil, Univ. Federal de Viçosa, Viçosa, MG, Brasil, 2014.

[11]A. R. Alves, I. B. Valente, W. B. Vieira, and G. S. Veríssimo, “Avaliação do comportamento de vigas mistas com conector Crestbond," in 5th Jornadas Portuguesas de Engenharia de Estruturas, Lisboa, 2014.

[12] A. R. Alves, I. B. Valente, W. B. Vieira, and G. S. Veríssimo, "Prospective study on the behavior of composite beams with an indented shear connector," J. Construct. Steel Res., vol. 148, pp. 508-524, Sep 2018, http://dx.doi.org/10.1016/j.jcsr.2018.06.015.

[13] M. C. Petrauski, "Simulação numérica do comportamento de vigas mistas de aço e concreto com conectores Crestbond," M.S. thesis, Dept. Eng. Civil, Univ. Federal de Viçosa, Viçosa, MG, Brasil, 2016.

[14] European Committee for Standardization. Eurocode 4: Design of Composite Steel and Concrete Structures - Part 1-1: General Rules and Rules for Buildings, EN 1994-1-1, 2004.

[15] S. Hong and A. H. Varma, "Analytical modeling of the standard fire behavior of loaded CFT columns," J. Construct. Steel Res., vol. 65, pp. 54-69, Jan 2009, http://dx.doi.org/10.1016/j.jcsr.2008.04.008.

[16] K. Wang and B. Young, "Fire resistance of concrete-filled high strength steel tubular columns," Thin-walled Struct., vol. 71, pp. 4656, Oct 2013, http://dx.doi.org/10.1016/j.tws.2013.05.005. 
[17] A. Espinós, M. L. Romero, and A. Hospitaler "Finite element analysis of the fire behavior of concrete filled circular hollow section columns," in Finite element modelling of innovative concrete-filled tubular columns under room and elevated temperature European Project FRISCC: Fire Resistance of Innovative and Slender Concrete Filled Tubular Composite Columns, A. Espinós and M. L. Romero, Editorial Universitat Politècnica de València, 2013, pp. 3-12.

[18] T. A. C. Pires, J. P. C. Rodrigues, J. J. R. Silva, and I. Garcia "Estudo paramétrico do comportamento ao fogo de colunas tubulares de aço preenchidas com betão," in IX Cong. Construção Metálica e Mista \& I Cong. Luso-brasileiro de Construção Metálica Sustentável, Porto, 2013.

[19] L. M. S. Laím, J. P. Rodrigues, A. M. Correia, and T. A. Pires "Numerical analysis of composite steel-concrete columns under fire conditions," in Finite element modelling of innovative concrete-filled tubular columns under room and elevated temperature European Project FRISCC: Fire Resistance of Innovative and Slender Concrete Filled Tubular Composite Columns, A. Espinós and M. L. Romero, Editorial Universitat Politècnica de València, 2013, pp. 33-44.

[20] European Committee for Standardization. Eurocode 2: Design of concrete structures - Part 1-2: General rules - Structural fire design, EN 1992-1-2, 2004.

[21] European Committee for Standardization. Eurocode 3: Design of Steel Structures - Part 1-2: General Rules - Structural Fire Design, EN 1993-1-2, 2005.

[22] European Committee for Standardization. Eurocode 4: Design of composite steel and concrete structures - Part 1-2: General rules Structural fire design, EN 1994-1-2, 2005.

[23] Associação Brasileira de Normas Técnicas. Fire-resistance requirements for building construction elements - Procedure, NBR 14432, 2005.

[24] International Organization for Standardization. Fire-resistance tests: elements of building construction - part 1.1: general requirements for fire resistance testing, ISO 834, 1999.

[25] T. T. Lie, "A procedure to calculate fire resistance of structural members," Fire Mater., vol. 8, pp. 40-48, Mar 1984, http://dx.doi.org/10.1002/fam.810080108.

Author contributions: Luiz Fernando Pereira do Prado developed this study under the guidance of Rodrigo Barreto Caldas; Larice Gomes Justino Miranda contributed in the analysis of the results and in the conclusion.

Editors: Bernardo Horowitz, Guilherme Aris Parsekian 